\title{
Effect Of Product Quality, Price Perception, And Promotion On Purchase Decisions At Pand's Muslim Department Store
}

\author{
Emil Yuliantie \\ Magister Management, Ahmad Dahlan University \\ *emilyuliatie77@gmail.com
}

\begin{abstract}
This study aims to (1) analyze the effect of product quality on purchasing decisions at Pand's Muslim Department Store. (2) To analyze the effect of price perceptions on purchasing decisions at Pand's Muslim Department Store. (3) Analyzing the effect of promotion on purchasing decisions at Pand's Muslim Department Store. This research model is a quantitative research with data collection techniques using a questionnaire. The sampling technique used purposive sampling. Samples to be taken are respondents who are consumers of Pand's Muslim Department Store. In this study, sampling was carried out by waiting for consumers who had finished making purchases at Pand's Muslim Department Store, consumers who were willing to be respondents, aged over 17 years, and consumers have visited at least 2 times. Data analysis using multiple linear regression. The results showed that (1) Product quality had a positive and significant effect on purchasing decisions, with a significance value of 0.040. (2) Price perception has a positive and significant effect on purchasing decisions, with a significance value of 0.047. (3) Promotion has a positive and significant effect on purchasing decisions, with a significance value of 0.000 . (4) Product quality, perceived price, and promotion have a positive and significant effect on purchasing decisions, with a significance value of 0.000 . with a significance value of 0.040 . (2) Price perception has a positive and significant effect on purchasing decisions, with a significance value of 0.047. (3) Promotion has a positive and significant effect on purchasing decisions, with a significance value of 0.000 . (4) Product quality, perceived price, and promotion have a positive and significant effect on purchasing decisions, with a significance value of 0.000 . with a significance value of 0.040 . (2) Price perception has a positive and significant effect on purchasing decisions, with a significance value of 0.047. (3) Promotion has a positive and significant effect on purchasing decisions, with a significance value of 0.000 . (4) Product quality, perceived price, and promotion have a positive and significant effect on purchasing decisions, with a significance value of 0.000 .
\end{abstract}

Keywords: product quality, price perception, promotions, purchasing decisions

\section{Preliminary}

In this globalization era, business competition is inevitable. Marketers who will sell their products, in the form of goods and services, must be able to fulfill what their consumers need and want, so that they can provide better value than their competitors. Islam justifies trading, commerce, and / or buying and selling and it also enters business.

Yogyakarta is one of the cities with the largest number of boutiques in Indonesia. Various kinds of boutiques have appeared in Yogyakarta, ranging from boutiques with segmentation ranging from students, university students, workers, to children. A boutique is a 


\section{Emil Yuliantie}

distribution shop that sells clothing products (t-shirts, shirts, flannels, bags, pants, wallets, etc.), which functions to accept deposits from various clothing company brands. Clothing is a manufacturer that produces all products with its own label. A garment can have its own shop or just leave its products.

Market competition accompanied by the emergence of competitors engaged in the same field or what is often referred to as the Red Ocean Strategy, indirectly affects a company's efforts to maintain its market share. Companies are required to always innovate so that new consumers or existing customers will continue to use the goods or services from the company. If the company can make the right innovation with a good understanding of consumer behavior, the company will have the opportunity to get more advantages compared to competitors. In relation to purchasing decisions, consumers have a crucial role in the existence of a business entity. Because almost every company activity is carried out to position the product so that it can be accepted by consumers.

The diversity of consumer wants and needs forces producers to make observations of what consumers want. By understanding consumer behavior, companies can design, understand and understand what is needed and what kind of goods or services consumers want. People are now very aware of the need for fashion that is more than just dressing, but also has to be trendy and keep up with fashion developments. Because most people today judge someone from the way they wear first or it can be called clothes that reflect one's personal identity. People, especially in Indonesia, no longer only rely on clothing stores in markets or malls to buy the fashion needs they will wear. Distribution stores or better known as boutiques are now an alternative for Indonesians to shop for their clothing needs. The boutique itself is a distribution shop that sells a variety of products, ranging from t-shirts, shirts, flannels, jackets, jeans, chinos, wallets, bags, shoes, and so on. It is different from boutiques and Factory Outlets (FO) where most boutiques only sell items in the boutique itself (especially women's products) and nowhere else. FO and other retailers do not make products, but only a place for other clothing companies to sell their products. Meanwhile, Pand's Muslim Department Store, apart from producing and selling its own products, also distributes and sells products from other clothing in the form of cooperation. jeans, chinos, purses, bags, shoes, etc. It is different from boutiques and Factory Outlets (FO) where most boutiques only sell items in the boutique itself (especially women's products) and nowhere else. FO and other retailers do not make products, but only a place for other clothing companies to sell their products. Meanwhile, Pand's Muslim Department Store, besides producing and selling its own products, also distributes and sells products from other clothing in the form of cooperation. jeans, chinos, purses, bags, shoes, etc. It is different from boutiques and Factory Outlets (FO) where most boutiques only sell items in the boutique itself (especially women's products) and nowhere else. FO and other retailers do not make products, but only a place for other clothing companies to sell their products. Meanwhile, Pand's Muslim Department Store, besides producing and selling its own products, also distributes and sells products from other clothing in the form of cooperation. but only a place for other clothing companies to sell their products. Meanwhile, Pand's Muslim Department Store, besides producing and selling its own products, also distributes and sells products from other clothing in the form of cooperation. but only a place for other clothing companies to sell their products. Meanwhile, Pand's Muslim Department Store, besides producing and selling its own products, also distributes and sells products from other clothing in the form of cooperation.

Product ideas can be born from an interest in a model, lifestyle, and the same hobby, thus forming a community. Then they started to produce their own goods, complete with 


\section{Emil Yuliantie}

merchandise, T-shirts, stickers, and so on. It is this specific need that encourages the community to come to the boutique looking for items that are not found in other stores.

The development of fashion but with a model that is more universal or acceptable to most people. Muslim clothes are still synonymous with young people, but it is possible that boutiques are also an ideal place to shop for clothes for parents and children. Currently, Muslim clothing shops have mushroomed in various big cities in Indonesia. Yogyakarta is also not spared from the many Muslim clothing shops.

Clothing stores often carry out promos in front of the store, lottery tickets to concerts, and product discounts. The promo aims to further boost sales, in addition to attracting the attention of new consumers who have never previously shopped in a store. Thus, it has the opportunity to expand its market in the city of Yogyakarta. Slowly but surely, Pand's Muslim Department Store is able to compete with other shops that have already been established. This is evident from the income of Pand's Muslim Department Store which has always increased from year to year. This can not be separated from the right promotions carried out by company management which are also supported by the quality of goods and product designs that are up to date or not outdated.

Pand's Muslim Department Store sales data from August 2018 to September 2019 has always experienced an increase in revenue from year to year. However, if examined in more detail, in 2019, to be precise, from June to September, the income of Pand's Muslim Department Store has decreased in a row, this decline is thought to be related to the decline in consumer purchasing decisions for products available at Pand's Muslim Department Store. Based on the data, it can be concluded that Pand's Muslim Department Store has always experienced a decrease in the number of visitors and the number of transactions from August 2018-November 2019. In September Pand's Muslim Department Store experienced a decrease of 365 visitors and 95 transactions and continued to experience a decrease of 66 visitors; 31 transactions and 55 visitors and 18 transactions. The decline in sales, followed by a decrease in the number of visitors and transactions, clearly worried the management of Pand's Muslim Department Store. Of course this will be an interesting thing to research. The problems that occur at Pand's Muslim Department Store cannot be separated from consumer or potential consumer purchasing decisions for clothing products available at Pand's Muslim Department Store.

Consumers in making decisions to buy a product offered are influenced by their perceptions of price, product, promotion, place (marketing mix) that have been implemented by the company so far. The relationship between price and purchasing decisions, namely the price affects consumer decisions in making purchases, the higher the price, the lower the purchase decision, on the contrary, if the price is low the purchase decision changes the higher. The recent increase in basic material prices has prompted producers to increase the selling price of their products, because basically the HPP for the products they produce automatically increases. For example, in September there was an increase in the price from IDR 255,000 to IDR 300,000.

The problem regarding the design of a product is one of the factors that need to get serious attention from management, especially the new product development team, because many target consumers are starting to question the design of a product that is able to meet the needs and desires of consumers. The brand selection carried out by Pand's Muslim Department Store aims to make the brands that sell their products at Pand's Muslim Department Store have a product design that is not outdated. Product quality is one of the determining factors for the level of consumer satisfaction after purchasing and using a product. Research conducted by Sulistyawati (2011) in which it was discussed that there are several stages to manage the quality of a product: quality planning, organizing for quality, direction for quality, control for the 


\section{Emil Yuliantie}

quality of the resulting product planning must be in accordance with consumer needs. In addition, the resulting product must reflect good quality. This is so that the product can be accepted and in accordance with consumer needs and can satisfy consumers.

Seeing that there is very tight competition in the Muslim fashion business, Pand's Muslim Department Store is making other efforts to introduce its products through promotions, among which are they often sponsor an event, Pand's Muslim Department Store products are often used as brand ambassadors at the event, distributing brochures about their products, and participating in various promotional events and exhibitions held in a number of regions. This is different from the promotions made by competitors of Pand's Muslim Department Store.

\section{Theoretical basis}

\section{Buying decision}

In understanding consumer behavior, there are many influences that underlie a person in making purchasing decisions for a product or brand. In most people, consumer buying behavior is often initiated and influenced by the number of stimuli from outside himself, either in the form of marketing stimuli or stimuli from other environments. The stimuli are then processed (processed) in themselves, according to their personal characteristics, before finally making a purchase decision. The personal characteristics of consumers used to process these stimuli are very complex, and one of them is the consumer's motivation to buy.

According to Schiffman and Kanuk (1994) in Albari (2010) states that motivation is a driving force from within individuals that forces them to take action. If someone has high motivation towards a certain object, then he will be motivated to behave in controlling the product. Conversely, if the motivation is low, then he will try to avoid the object in question. The implication in marketing is for the possibility that the person is interested in buying the product or brand that the marketing offers or not.

According to Kotler and Armstrong (2010), purchasing decisions are the final behavior of consumers, both individuals and households, who buy goods and services for personal consumption. According to Kotler (2010) purchasing decisions are the way individuals, groups, organizations choose, buy, use and utilize goods, services, ideas, experiences in order to satisfy their needs and desires. From this definition, it can be concluded that purchasing decisions are actions taken by individuals, groups, or organizations to select, buy, use and utilize goods, services, ideas, experiences in order to satisfy needs and desires.

\section{Product quality}

Kotler (2010: 13) states that a product is anything that can be offered to satisfy a need and desire. According to Dharmmesta and Irawan (2001: 165) a product is a complex characteristic, both palpable and intangible, including packaging, color, company and retail prestige accepted by buyers to satisfy their wants or needs. Kotler and Armstrong (2010) state that "Product quality is the ability of a product to perform its functions which include durability, reliability, accuracy, ease of operation and product repair and other product attributes". Product quality is an important thing that every company must strive for if it wants the products to be competitive in the market. Nowadays, because the economic capacity and education level of the community tends to increase, some people are increasingly critical in consuming a product. Consumers always want to get quality products according to the price paid, even though there are some people who think that expensive products are quality products.

According to Tjiptono (2005), the understanding of quality is then expanded into "fitness for use" and "conformance to requirements". Quality reflects all dimensions of a product 


\section{Emil Yuliantie}

offering that yields benefits to customers. The term value is often used to refer to the relative quality of a product in relation to the price of the product concerned. The impact of quality on market share usually depends on the definition of quality. If quality is defined as reliability, high aesthetics (how the product looks or feels), or conformation (the degree to which the product meets specified standards) then the relationship to market share is positive. If product quality is defined in the context of excellent or more attractive appearance,

\section{Price Perception}

In marketing, perception is more important than reality, because consumer perceptions affect the actual behavior of consumers. Perception is the process by which we select, organize, and translate input information to create a new world picture, Kotler and Keller (2009). Price perceptions are related to how price information is fully understood by consumers and provides deep meaning to them.

Price perception is the tendency of consumers to use price in providing an assessment of the suitability of product benefits. The assessment of the price of a product benefit is said to be expensive, cheap or moderate for each individual is not the same, because it depends on the individual's perception that is motivated by the environment and the condition of the individual itself. Basically, customers in assessing the price of a product do not depend only on the nominal value of the price but on their perception of the price. Companies must set prices appropriately in order to be successful in marketing goods or services. In setting the price, the company must consider the factors in determining its pricing policy, so that the price that is later applied can be accepted by consumers.

a. Cost becomes lower limit.

b. Competitor prices and the price of substitute goods are orientation points that the company needs to consider.

c. The customer's assessment of the unique product features of the company offering imposes an upper limit on the price.

\section{Promotion}

According to Dharmmesta and Irawan (2001: 349) promotion is a one-way flow of information or persuasion designed to direct a person or organization to actions that create exchanges in marketing. The main purpose of promotion is to inform, influence and persuade and remind target customers about marketing and marketing mix. By paying attention to the above, it requires preparation or means of promotion so that what the company wants can meet targets and be efficient. Promotion means can be:
a. Advertisement
b. Sales promotion
c. Publicity
d. Private Selling

According to Belch (2004) promotion is a way to communicate product advantages in order to persuade target customers to make purchases (communication). Promotion variables include, among others, sales promotion, advertising, sales force, public relations, and direct marketing. Promotion variables or what is commonly called Kotler's (2010) marketing communication mix:

a. Advertisingnamely all forms of non-personal presentation and promotion of ideas, goods, or services by a designated sponsor for a fee.

b. Sales promotion, namely short-term incentives to encourage the desire to try or purchase products and services. 


\section{Emil Yuliantie}

c. Public relations and publicity, namely various programs designed to promote and / or protect the company's image or individual products produced.

d. Personal selling, namely direct interaction between one or more prospective buyers with the aim of making a sale.

e. Direct marketing, namely conducting direct marketing communications to get responses from certain customers and prospects, which can be done by using letters, telephone, and other non-personal communication tools.

\section{Research Model}

This research model is a research quantitative, quantitative research is basically testing the theory and the theory used is relevant (Pasolong, 2005: 127). This study examines the effect of product quality, price perception, and promotion on purchasing decisions at Pand's Muslim Department Store. In accordance with the explanation above, the design model of this study places product quality, price perception, promotion as independent variables and purchasing decisions as the dependent variable. The research model is described as follows:

\section{Data Collection Techniques}

The type of data used in this research is primary data. Primary data is a source of research data obtained directly from the original source (not through intermediary media). Primary data is specifically collected by researchers to answer research questions. The primary data used in this study were obtained from questionnaires filled out by respondents directly to buyers at Pand's Muslim Department Store.

Research instruments in a quantitative approach are commonly referred to as data collection tools. Data collection tools used in the field, in the form of a closed questionnaire. Arikunto (2010: 102-103) states that a closed questionnaire is a questionnaire that is presented in such a form that the respondent only has to give a check list $(\sqrt{ })$ in the appropriate column or place, with a direct questionnaire using a multilevel scale.

This questionnaire is used to find out data about the effect of product quality, price perception, and promotion On purchasing decisions at Pand's Muslim Department Store. Respondents are expected to answer all the questions in the questionnaire, by choosing one of the answers provided. In this study the answers given by the respondents were then scored by referring to a Likert scale, where each item of question was provided with 5 (five) answer choices, namely:

$\begin{array}{lll}\text { SS } & : \text { Strongly agree } & \text { Score 5 } \\ S & : \text { Agree } & \text { Score 4 } \\ N & : \text { Neutral } & \text { Score 3 } \\ T S & : \text { Disagree } & \text { Score 2 } \\ \text { STS } & : \text { Strongly Disagree } & \text { Score 1 }\end{array}$

\section{Research Result}

\section{Validity and Reliability}

a. Validity test

An instrument that is valid or valid has high validity. Information, that is, if the rxy value is obtained, it will be consulted with the product moment price in the table at the 0.05 significance level. If rxy> rtab then the item is declared valid. The full validity test results are 


\section{Emil Yuliantie}

presented in Table 1 as follows:

Table 1. Instrument Validity Test Results

\begin{tabular}{|c|c|c|c|c|c|}
\hline No. & Variable & Grain & $r$ count & r table & Information \\
\hline \multirow[t]{4}{*}{1} & \multirow[t]{4}{*}{ Product quality } & Item 01 & 0.801 & 0.334 & Valid \\
\hline & & Item 02 & 0.557 & 0.334 & Valid \\
\hline & & Item 03 & 0.583 & 0.334 & Valid \\
\hline & & Item 04 & 0.801 & 0.334 & Valid \\
\hline \multirow[t]{4}{*}{2} & \multirow[t]{4}{*}{ Price Perception } & Item 01 & 0.673 & 0.334 & Valid \\
\hline & & Item 02 & 0.964 & 0.334 & Valid \\
\hline & & Item 03 & 0.964 & 0.334 & Valid \\
\hline & & Item 04 & 0.925 & 0.334 & Valid \\
\hline \multirow[t]{4}{*}{3} & \multirow[t]{4}{*}{ Promotion } & Item 01 & 0.955 & 0.334 & Valid \\
\hline & & Item 02 & 0.595 & 0.334 & Valid \\
\hline & & Item 03 & 0.955 & 0.334 & Valid \\
\hline & & Item 04 & 0.955 & 0.334 & Valid \\
\hline \multirow[t]{4}{*}{4} & \multirow[t]{4}{*}{ Buying decision } & Item 01 & 0.952 & 0.334 & Valid \\
\hline & & Item 02 & 0.866 & 0.334 & Valid \\
\hline & & Item 03 & 0.537 & 0.334 & Valid \\
\hline & & Item 04 & 0.952 & 0.334 & Valid \\
\hline
\end{tabular}

Source: primary data

\section{b. Reliability Test}

After the validity test is carried out the next step is the reliability test. The reliability test was only carried out on valid questionnaire items. Arikunto (2010: 221) states that reliability shows in one sense that an instrument can be trusted enough to be used as a data collection tool because the instrument is good. The instrument reliability test used the "alpha cronbach" formula using the SPSS version 20 computer program. The complete reliability test results are presented in Table 2 as follows:

Table 2. Reliability Test Results

\begin{tabular}{|l|l|l|l|}
\hline No. & \multicolumn{1}{|c|}{ Variable } & $\begin{array}{c}\text { Reliability } \\
\text { Coefficient }\end{array}$ & Information \\
\hline 1 & Product quality & 0.753 & Reliable \\
\hline 2 & Price Perception & 0.930 & Reliable \\
\hline 3 & Promotion & 0.865 & Reliable \\
\hline 4 & Buying decision & 0.855 & Reliable \\
\hline
\end{tabular}

Source: primary data (2020)

\section{Research Data}

Variable descriptive analysis is a description of the variables obtained based on the respondent's answers to the questions / statements based on the indicators to be studied. The tendency of respondents' answers will be seen for all research variables. The category of each variable is determined by first creating class intervals 


\section{Emil Yuliantie}

Teble 3. Respondents' Answer Categories

\begin{tabular}{|c|c|c|c|}
\hline No. & Variable & Mean & Category \\
\hline 1 & Product quality & 2.82 & Pretty good \\
\hline 2 & Price Perception & 3.11 & Pretty good \\
\hline 3 & Promotion & 3.04 & Pretty good \\
\hline 4 & Buying decision & 3.05 & Pretty good \\
\hline
\end{tabular}

Source: primary data (2020)

\section{Hypothesis Test Results}

The analysis technique used to test the first, second, and second hypotheses used partial correlation analysis techniques, while to test the fourth hypothesis using multiple regression analysis techniques. The results of the hypothesis test are presented as follows:

a. Multiple Linear Test Results

Multiple linear regression analysis aims to determine the direction of the relationship between the independent variable and the dependent variable whether each independent variable is positively or negatively related and to predict the value of the dependent variable if the value of the independent variable has increased or decreased.

Table 4. Multiple Linear Test Results

\begin{tabular}{|c|c|c|c|c|c|c|}
\hline \multicolumn{7}{|c|}{ Coefficientsa } \\
\hline \multirow{2}{*}{\multicolumn{2}{|c|}{ Model }} & \multicolumn{2}{|c|}{$\begin{array}{l}\text { Unstandardized } \\
\text { Coefficients }\end{array}$} & $\begin{array}{l}\text { Standardized } \\
\text { Coefficients }\end{array}$ & \multirow[t]{2}{*}{$\mathrm{t}$} & \multirow{2}{*}{ Sig. } \\
\hline & & $\mathrm{B}$ & Std. Error & Beta & & \\
\hline \multirow[t]{4}{*}{1} & (Constant) & .323 & .253 & & 1,273 & .208 \\
\hline & Product quality & .122 & .051 & .097 & 2,096 & .040 \\
\hline & Price Perception & .119 & .061 & .138 & 1,934 & .047 \\
\hline & Promotion & .754 & .092 & .767 & 8,201 & .000 \\
\hline & ndent Variable: & chase I & ision & & & \\
\hline
\end{tabular}

Based on the table above, the regression equation line can be seen as follows:

$$
\mathrm{Y}=0.323+0.122 \times 1+0.119 \mathrm{X} 2+0.754 \times 3
$$

b. Partial Test ( $\mathrm{t}$ test)

The $t$ test is a means of testing to determine whether the independent variable individually affects the dependent variable. The results are presented in the table as follows:

Table 5. Results of Partial Test Analysis (t test)

\begin{tabular}{|l|l|r|r|r|r|r|}
\hline \multicolumn{2}{|c|}{ Model } & \multicolumn{2}{c|}{$\begin{array}{c}\text { Unstandardized } \\
\text { Coefficients }\end{array}$} & $\begin{array}{l}\text { Standardized } \\
\text { Coefficients }\end{array}$ & \multirow{2}{*}{$\mathrm{t}$} & \multirow{2}{*}{ Sig. } \\
\cline { 3 - 8 } \multicolumn{2}{|c|}{} & B & Std. Error & Beta & & \\
\hline \multirow{3}{*}{1} & (Constant) & .323 & .253 & & 1,273 & .208 \\
\cline { 2 - 7 } & Product quality & .122 & .051 & .097 & 2,096 & .040 \\
\cline { 2 - 7 } & Price Perception & .119 & .061 & .138 & 1,934 & .047 \\
\cline { 2 - 7 } & Promotion & .754 & .092 & .767 & 8,201 & .000 \\
\hline \multicolumn{2}{|l|}{ a. Dependent Variable: Purchase Decision } & & & \\
\hline
\end{tabular}




\section{Emil Yuliantie}

Based on the results of the analysis in table 4.5 above, it can be explained as follows:

1) From the product quality variable data in the table above, a significance result of 0.040 is less than $0.05(0.040<0.05)$, so Ho is rejected, meaning Ha which reads "Product quality has a positive and significant effect on purchasing decisions ", accepted.

2) From the price perception variable data in the table above, the significance results obtained are 0.047 less than $0.05(0.047<0.05)$, so Ho is rejected, meaning Ha which says "Perception of prices has a positive and significant effect on purchasing decisions ", accepted.

3) From the data on the promotion variable in the table above, the significance results are 0.000 less than $0.05(0.000<0.05)$, so Ho is rejected, meaning Ha which says "Promotion has a positive and significant effect on purchasing decisions", accepted.

c. Simultaneous Test (F Count)

The $\mathrm{F}$ test is a means of testing to determine whether the independent variables jointly (simultaneously) affect the dependent variable. The results of data analysis using the SPSS version 17.0 program obtained the following calculations:

Table 6. Multiple Analysis Results (F)

\begin{tabular}{|l|l|l|l|l|l|c|}
\hline \multicolumn{7}{|c|}{ ANOVAb } \\
\hline \multicolumn{2}{|c|}{ Model } & $\begin{array}{c}\text { Sum of } \\
\text { Squares }\end{array}$ & df & $\begin{array}{c}\text { Mean } \\
\text { Square }\end{array}$ & F & Sig. \\
\hline \multirow{2}{*}{1} & Regression & 300,645 & 3 & 100,215 & 832,936 & $.000 \mathrm{a}$ \\
\cline { 2 - 7 } & Residual & 7,941 & 66 & .120 & & \\
\cline { 2 - 7 } & Total & 308,586 & 69 & & & \\
\hline $\begin{array}{l}\mid l \\
\text { a. Predictors: (Constant), Promotion, Product Quality, Price } \\
\text { Perception }\end{array}$ & \\
\hline \multicolumn{2}{|l|}{ b. Dependent Variable: Purchase Decision } & & \\
\hline
\end{tabular}

Based on table 4.6 above, the calculated F coefficient is 832.936 and the Sig. 0,000 $<0.05$ then Ho is rejected and Ha which reads "Product quality, price perception, and promotion have a positive and significant effect on purchasing decisions", accepted.

d. Coefficient of Determination (R2)

The coefficient of determination (R2) is basically used to measure the ability of the regression model to explain the variation in the dependent variable. The results of the analysis in table 4:11 are as follows:

Table 7. Analysis of the Coefficient of Determination (R2)

\begin{tabular}{|l|c|c|c|c|}
\hline \multicolumn{5}{|c|}{ Model Summary } \\
\hline Model & $\mathrm{R}$ & R Square & $\begin{array}{c}\text { Adjusted R } \\
\text { Square }\end{array}$ & $\begin{array}{c}\text { Std. Error of the } \\
\text { Estimate }\end{array}$ \\
\hline 1 & $.987 \mathrm{a}$ & .974 & .973 & .34686 \\
\hline $\begin{array}{l}\text { a. Predictors: (Constant), Promotion, Product Quality, Price } \\
\text { Perception }\end{array}$ \\
\hline
\end{tabular}

From the table above, it is known that the correlation coefficient is 0.987 and the coefficient of determination $\mathrm{r}$ ( $\mathrm{xy}$ ) of 0.974 , which means the influence of product quality, price 


\section{Emil Yuliantie}

perception, and promotion on purchasing decisions is $97.4 \%$. The coefficient of determination or R square at 0.974 means that the variation in purchasing decision variables can be explained by the independent variable Product quality, price perception, and promotion of $97.4 \%$, while the remaining $2.6 \%$ is explained by other variables not included in this study.

\section{Discussion}

Based on some of the research results above, the research results will be discussed as follows.

1) Effect of product quality on purchasing decisions

Based on the results of the study, it shows that product quality has a positive and significant effect on purchasing decisions, with a regression coefficient of X1 0.040 . The product quality referred to in this study refers to indicators of durability, conformity to specifications, comfort in use, and attractive models. Durability in this case is the durability of Pand's Muslim Department Store products which have a longer usage period than other similar brands. Thus, the more durable the durability of the goods will increase consumer purchasing decisions for Pand's Muslim Department Store products. Compliance with the required specifications means that Pand's Muslim Department Store products are in line with what consumers need. Thus, the more appropriate and specific the goods offered, to what is needed by consumers, will increase consumer purchasing decisions for Pand's Muslim Department Store products. Convenience in use, meaning that Pand's Muslim Department Store products are very comfortable when used by consumers. Thus the more comfortable this item is when used by consumers, it will increase purchasing decisions for Pand's Muslim Department Store products. The ease of maintenance is how easy it is to maintain Pand's Muslim Department Store products. This means that it's getting easiermaintenance will improve product purchase decisions Pand's Muslim Department Store.

Pand's Muslim Department Store products have various and attractive models. This means that the more variety of attractive models and designs it will increase the purchasing decision for Pand's Muslim Department Store products. This is as suggested by Kotler (2005) that consumer decisions in purchasing are influenced by company stimulation, including product quality so as to produce purchasing decisions based on product choice, brand choice, supplier choice, purchase time, purchase amount. This means that the better the consumer's perception of the three dimensions will affect the strength of the decision to buy the productPand's Muslim Department Store. This research is supported by research conducted by Haryati (2003) which states that product quality has a significant effect on post-purchase decisions for Avon products in Surakarta. Arbi (2016) added that product quality has a significant positive effect on purchasing decisions.

2) The effect of price perceptions on purchasing decisions

Based on the results of the study, it shows that price perceptions have a positive and significant effect on purchasing decisions, with a regression coefficient of X2 0.047.This means that the better the price is perceived by consumers, the higher the level of purchasing decisions at Pand's Muslim Department Store. Price perception in this study refers to several indicators including: prices that are comparable to quality, affordable prices, varying prices, and competitive prices from other brands. Thus, the better the consumer's perception of the suitability of quality with varied and affordable prices, and with prices that are quite competitive from other distributions, it will increase purchasing decisions at Pand's Muslim Department Store.This study is in line with the results of Arbi's (2016) study that price 


\section{Emil Yuliantie}

perceptions have a significant positive effect on purchasing decisions. Supported by Akbar's research (2012), it shows that price has a significant effect on purchasing decisions for Toshiba notebooks. The results of Gusniar's (2016) research show that there is a positive and significant influence between price on the decision to purchase hand and body lotion products with the Citra brand in students of the Faculty of Economics and Business UDINUS Semarang.

\section{3) The effect of promotion on purchasing decisions}

Based on the research results, it shows that promotion has a positive and significant effect on purchasing decisions, with a regression coefficient of X3 0,000.This means that the better the promotion carried out by Pand's Muslim Department Store in the eyes of consumers, the higher the level of purchasing decisions at the House Of Smith distribution. The promotion in question is a promotion that can trigger transactions so that consumers decide to buy products offered by Pand's Muslim Department Store. Thus the company's commitment to always satisfy its customers, it will also increase purchasing decisions at Pand's Muslim Department Store.

This study is in accordance with the opinion of Dharmmesta and Irawan (2001) which states that the main purpose of promotion is to inform, influence and persuade and remind target customers about marketing and marketing mix. Promotion productPand's Muslim Department Store done by giving discounts, advertisements, attractive brochures and direct sales through dealers. Consumer interest in these promotional attributes can influence consumer intentions to buy productsPand's Muslim Department Store. This study is in accordance with Prasetyo's (2004) research that promotion has a significant effect on purchasing decisions for Chinese brand VCD player products in Surakarta. Added to the results of research conducted by Khakim (2014) shows that promotion has a positive and significant effect on iPhone purchase decisions in Semarang City, meaning that the higher the promotion of the iPhone, the higher the decision to buy an iPhone in Semarang City. Conversely, if the lower the iPhone promotion, the lower the iPhone purchase decision in Semarang City.

The results of this study are in line with Sunyoto's (2012: 154) theory, which states that promotion is one of the determining factors for the success of a marketing program. Regardless of the quality of a product, if consumers have never heard of it and are not sure that the product will be of use to them, then they will never buy it. The results of this study are in line with Tjiptono's (2005: 219) theory, that sales promotion is a form of direct persuasion through the use of various incentives that can be arranged to stimulate immediate product purchases and increase the number of goods purchased by customers. The results of this study are in line with the theory (Swastha and Irawan, 2005: 349), that promotion is all types of marketing activities aimed at driving demand.

4) The influence of product quality, price perception, and promotion on purchasing decisions

Based on the results of the study, it shows that product quality, price perception, and promotion have a positive and significant effect on purchasing decisions, the coefficient of determination or R square at 0.974 , means that variations in purchasing decision variables can be explained by the independent variables Product quality, price perception, and promotion of $97.4 \%$, while the rest is $2.1 \%$, explained by other variables not included in this study. The results of this study are in line with the research of Maulana et al. (2014: 1391), that the promotion, price and innovation variables together have a significant influence on the purchasing decision of Nike futsal shoes. This means that promotions, prices and innovations offered by Nike have an influence on consumers in making decisions to buy Nike futsal shoes. This result is supported by research conducted by Suti (in Maulana et al., 2010: 1391) which states that the variables of product quality, price and promotion have a significant effect on 


\section{Emil Yuliantie}

purchasing decisions. This result is also supported by research conducted by Publica and Widodo (2016) which states that the variable product quality (H1), product design $(\mathrm{H} 2)$, and brand (H3) simultaneously have a positive and significant effect on the purchase decision process (Y) on Converse shoes. All Stars. This shows if the three variables are jointly applied in marketing activities that can influence Telkom University students class of 2012-2015 in making purchases. Ansah's (2017) research result added that the product design,

\section{Conclusion}

Based on the results of the research and the results of the data analysis that has been carried out, the following conclusions are obtained.

1. Product quality has a positive and significant effect on purchasing decisions, with a significance value of $0.040<0.05$.

2. Price perception has a positive and significant effect on purchasing decisions, with a significance value of $0.047<0.05$.

3. Promotion has a positive and significant effect on purchasing decisions, with a significance value of $0.000<0.05$.

4. Product quality, perceived price, and promotion have a positive and significant effect on purchasing decisions, with a significance value of $0.000<0.05$.

\section{Bibliography}

Albari. 2002. Knowing Consumer Behavior Regarding Motivational Research ", Journal of Business Strategy, No. 7 Vol. 1.

Ardi Ansah. 2017. The Influence of Product Design, Promotion, and Brand Image on Purchasing Decisions. Amwaluna, Vol. 1 No.2 July, 2017, pp. 178-189.

Arikunto, Suharsimi. 2010. Research procedures; a practical approach. Revised edition Jakarta: Rineka Cipta.

Babin. 2011. "Exploring marketing research. four salemba publishers ". Jakarta: Rineka Cipta. Bayu Januar Rachman \& Suryono Budi Santoso. 2015. Analysis of the Influence of Product

Design and Promotion on Stability of Purchasing Decisions Mediated by the Study Brand Image on Customer Distro Jolly Roger Semarang. Diponegoro Journal of Management. Volume 4, Number 1, Year 2015, Pages 1-15.

Belch, George E. 2004. Advertising and Promotion: "An Integrated Marketing Communications Perspective". 6th edtion. Mc Graw-Hill Company, New York.

Brahm Nehru Facta Publica \& Arry Widodo.2016. The Influence of Product Quality, Product Design and Brand on the Purchasing Decision Process of Converse All Stars Shoes. Study of Telkom University Students Class of 2012-2015. e-Proceeding of Management: Vol. 3, No.2.

Cucun Fery Tri Arbi. 2016. The effect of product quality, price perception, and promotion on purchasing decisions at the house of smith distribution Semarang. Essay. Semarang: Stikubank University.

Dharmesta, Basu Swastha \& T. Hani Handoko, 2000. Marketing Management Consumer Behavior Analysis. Third Edition, Yogyakarta: BPFE.

Muhammad \& Fauroni, RL 2002. Vision of the Qur'an on ethics and business, Jakarta: Salemba Diniyah: 


\section{Emil Yuliantie}

Ghazali, Imam. 2011. Multivariate analysis application with SPSS program. Semarang: Diponegoro University Publishing Agency.

Hadi, Sutrisno. 1991. Item Analysis for Questionnaire, Test, and Value Scale Instruments with BASICA. Yogyakarta: Andi Ofset.

Haryati. 2003. "Analysis of Factors Affecting the Level of Satisfaction of Avon Product Consumers Surakarta", Thesis. Surakarta: FE Batik Islamic University.

Komalasari, Kokom. 2010. "Contextual learning and applications". Bandung: Refika Aditama. Kotler, Philip \& Armstrong. 2006. Marketing principles. Volume 2, 8th ed.. Jakarta: Erlangga. Kotler, Philip \& Keller, Kevin Lane. 2009. "Marketing management", Jakarta: Erlangga.

Kotler, Philip. 2000. Marketing management, Millennium Edition, Jakarta, Prehallindo.

Kotler, Philip. 2002. "Marketing management", second volume. 10th ed. Jakarta: Prenhallindo. Kotler, Philip. 2008. Principles of Marketing, Volume 1, Jakarta: Erlangga.

Langgeng, SN 2015. The Influence of Quality, Price, Location and Promotion on Purchasing Decisions of Distro Distro Distributor Outlet Rown Division in Solo ", Publication Text, Muhammadiyah University of Surakarta.

Maulana MI Umaternate., WJFA Tumbuan., R. Taroreh. 2014. Promotions, Prices and Innovations Influence the Purchase Decision of Nike Futsal Shoes at Akbar Ali Sport Manado. EMBA Journal, 2 2: 1381-1392.

Muhammad Lutfi Khakim. 2014. The Influence of Price, Brand Image, Product Quality, and Promotion on Iphone Purchasing Decisions in Semarang City. Description. Semarang: Dian Nuswantoro University Semarang.

Pasolong, H. 2005. Administrative Research Methods. Makassar: The Lephas Unhas Research Institute.

Prasetyo, Badhik, 2004, "Analysis of Consumer Behavior on Purchasing Decisions of Video CD Player Products from China. Survey on the Kadipiro Banjarsari Community", Thesis. Surakarta: FE, Slamet Riyadi University.

Rachmady Saputra, Sasongko, \& Agus Budiharjo. 2015. The Influence of Product Innovation and Promotion on Purchasing Decisions at the Klanrock House Concept Store Distro in Jember. e- SOSPOL XXX.

Sugiyono. 2011. Educational Research Methods: Quantitative Approaches, Qualitative, and R \& D. Bandung: Alfabeta.

Sulistyawati, Praba. 2011. Analysis of the Influence of Brand Image and Product Quality on Purchasing Decisions of Acer Laptop Brands in Semarang. Diponegoro University. Essay. Semarang: Diponegoro University.

Sunyoto. 2012. Basics of Marketing Management. Yogyakarta: CAPS.

Swastha, Basu \& Irawan. 2005. Modern Marketing Management. Yogyakarta: Liberty.

Tjiptono, Fandy. 2005. Marketing Services, First Edition. Malang: Bayu Media Publishing

Wahyudi, Rendang. 2013. "Analysis of the Effect of Product Quality and Brand Equity on Edible Oil Purchase Decisions", Journal of EMBA Vol.1 No.3, Sam Ratulangi University, Manado.

Yuniar, Agung. 2012. The Influence of Price Perception, Distribution Channels, and Promotion on the Decision to Purchase Bottled Drinking Water with the Aqua Brand Brand, Thesis, University of Stikubank, Semarang. 